\title{
High Prevalence of Cross-Resistance to Aminoglycosides in Fluoroquinolone-Resistant Escherichia coli Clinical Isolates
}

\author{
Naoyuki Tsukamoto ${ }^{a, b}$ Yasuo Ohkoshi ${ }^{a, b}$ Torahiko Okubo $^{d}$ Toyotaka Sato $^{d}$ \\ Osamu Kuwaharac Nobuhiro Fujii ${ }^{\mathrm{a}}$ Yutaka Tamurad Shin-ichi Yokota $^{\mathrm{a}}$

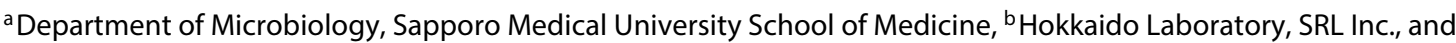 \\ 'Sapporo Clinical Laboratories Inc., Sapporo, and d Laboratory of Food Microbiology and Food Safety, Department \\ of Health and Environmental Sciences, School of Veterinary Medicine, Rakuno Gakuen University, Ebetsu, Japan
}

\section{Key Words}

Escherichia coli · Fluoroquinolones - Aminoglycosides .

Extended-spectrum $\beta$-lactamases · Antibiotic resistance

\begin{abstract}
Background: Multidrug-resistant Escherichia coli, especially a lineage of O25b:H4-ST131, has increased and spread worldwide. The surveillance of cross-resistance of $E$. coli is necessary. Methods: Cross-resistance to fluoroquinolones (FQs) and aminoglycosides (AGs) was examined in E. coli isolated in Hokkaido Prefecture, Japan, between 2008 and 2009. Results: Gentamicin (GEN) resistance was more common in FQresistant isolates (30/112 strains; $26.8 \%$ ) than in FQ-susceptible isolates (2/100 strains; $2 \%)$. The frequency of GEN resistance was similar in two groups of FQ-resistant strains, O25b:H4-ST131 genotype (22/87 strains; $25.3 \%$ ) and a group of other FQ-resistant genotypes (8/25 strains; $32.0 \%)$. The main AG resistance gene was aac(3)-II (87.5\% of GEN-resistant strains). The only amikacin-resistant strain which was FQ resistant carried the $a a c\left(6^{\prime}\right)-I b-c r$ gene. CTX-M type extended-spectrum $\beta$-lactamase (ESBL) genes were also found in FQ-resistant strains at a high frequency. However, the number of strains with both ESBL and AG-modifying enzyme genes was relatively low (8 strains). Conclusion: All FQ-resis-
\end{abstract}

tant strains, not only O25b:H4-ST131, appeared to preferentially acquire ESBL genes and/or genes encoding AG-modifying enzymes; however, the acquisitions of these genes seemed to occur independently.

(c) 2014 S. Karger AG, Basel

\section{Introduction}

Escherichia coli is a commensal bacterium found in the intestines of most animals, including humans. However, a small proportion of $E$. coli strains that share specific pathogenic factors are highly enteropathogenic [1]. Commensal strains of $E$. coli that have colonized the intestines may cause extraintestinal diseases, such as urinary tract infections as a primary infection $[2,3]$. Pneumonia and septicemia, which result in considerable morbidity and mortality, may be caused as opportunistic infections. $E$. coli is the most common causative agent of urinary tract infections, accounting for approximately $80 \%$ of uncomplicated community-acquired urinary tract infections [4, 5]. Fluoroquinolones (FQs) are often used as first-choice

N.T. and Y.O. contributed equally to this work.

\section{KARGER}

E-Mail karger@karger.com

www.karger.com/che
C 2014 S. Karger AG, Basel

0009-3157/14/0595-0379\$39.50/0 
antibiotics in the treatment of urinary tract infections; however, FQ-resistant E. coli strains have become a problem in urology. In addition, multidrug-resistant strains of $E$. coli producing extended-spectrum $\beta$-lactamases (ESBLs) and metallo- $\beta$-lactamases, namely carbapenemases, have become more common [6-9]. A lineage of the multilocus sequence type ST131, belonging to O25b:H4, has recently spread worldwide [10-13]. This lineage is FQ resistant and often acquires ESBL genes, particularly the CTX-M-15 of group 1. In contrast, other ESBL genes, particularly CTX-M groups 9 (CTX-M-14 and 27) and 2 (CTX-M-2), are dominant in Japanese O25b:H4-ST131 strains [14, 15]. However, CTX-M15-producing O25b:H4-ST131 strains have been found in recent years in Japan [16].

In $E$. coli, resistance to other antibiotics, such as carbapenems and aminoglycosides (AGs), has become a concern [17]. These antibiotics are occasionally used to treat severe systemic infections, such as sepsis. The mechanism underlying resistance to FQs involves somatic point mutations in the target genes of topoisomerase IV and DNA gyrase [18], whereas that underlying resistance to $\beta$-lactams is usually the acquisition of $\beta$-lactamase genes in Gram-negative bacteria [19]. Resistance to AGs mainly occurs through the acquisition of genes encoding AGmodifying enzymes, such as acetyltransferase (aac), phosphotransferase (aph) and nucleotidyltransferase (ant) genes [20-23]. Numerous types of AG-modifying enzymes have been identified and each provides resistance to specific AGs according to their substrate specificity. On the other hand, acquisition of $16 \mathrm{~S}$ rRNA methylase genes $(\mathrm{rtm} A, \mathrm{rtm} B$ and $\operatorname{armA})$, point mutations in rRNA and increase of the activity of efflux pumps are also involved in the molecular mechanisms of AG resistance [20, 2325]. These mechanisms provide resistance to various types of AGs. In this study, we screened for AG resistance among FQ-resistant and FQ-susceptible E. coli clinical isolates obtained from patients in Hokkaido Prefecture, Japan.

\section{Materials and Methods}

\section{Bacterial Isolates}

E. coli strains $(\mathrm{n}=478)$ isolated from various human clinical specimens during 2008 and 2009 were collected, identified and stocked in Sapporo Clinical Laboratory Inc. (Sapporo, Japan) as described previously [15]. The strains were randomly selected and strains isolated from the same patients were omitted. These laboratory samples were obtained from the entire area of Hokkaido Prefecture, Japan. Identification was performed using the MicroScan WalkAway 40 system (Siemens Healthcare Diagnostics, Tokyo, Japan). This study was approved by the review boards of the rele-
Table 1. PCR primer sets used to detect genes encoding AG-modifying enzymes

\begin{tabular}{|c|c|c|c|}
\hline Target & & Sequence & Ref. \\
\hline \multirow[t]{2}{*}{$\operatorname{aac}(3)-I$} & $\mathrm{~F}$ & $5^{\prime}$-ACC TAC TCC CAA CAT CAG CC-3' & {$[28]$} \\
\hline & $\mathrm{R}$ & 5'-ATA TAG ATC TCA CTA CGC GC-3' & \\
\hline \multirow[t]{2}{*}{$\operatorname{aac}(3)-I I$} & $\mathrm{~F}$ & $5^{\prime}$-TGA AAC GCT GAC GGA GCC TC-3' & [29] \\
\hline & $\mathrm{R}$ & 5'-GTC GAA CAG GTA GCA CTG AG-3' & \\
\hline \multirow[t]{2}{*}{$\operatorname{aac}(3)-I I I$} & $\mathrm{~F}$ & $5^{\prime}$-CAC AAG AAC GTG GTC CGC TA-3' & {$[28]$} \\
\hline & $\mathrm{R}$ & $5^{\prime}$-AAC AGG TAA GCA TCC GCA TC-3' & \\
\hline \multirow[t]{2}{*}{$\operatorname{aac}(3)-I V$} & $\mathrm{~F}$ & $5^{\prime}$-GTG TGC TGC TGG TCC ACA GC-3' & [29] \\
\hline & $\mathrm{R}$ & $5^{\prime}$-AGT TGA CCC AGG GCT GTC GC-3' & \\
\hline \multirow[t]{2}{*}{$\operatorname{ant}(2 ”)-I$} & $\mathrm{~F}$ & $5^{\prime}$-GGG CGC GTC ATG GAG GAG TT-3' & [29] \\
\hline & $\mathrm{R}$ & $5^{\prime}$-TAT CGC GAC CTG AAA GCG GC-3' & \\
\hline \multirow[t]{2}{*}{$a a c\left(6^{\prime}\right)-I b$} & $\mathrm{~F}$ & 5'-TTGCGATGCTCTATGAGTGGCTA-3' & {$[31]$} \\
\hline & $\mathrm{R}$ & 5'-CTCGAATGCCTGGCGTGTTT-3' & \\
\hline \multirow[t]{2}{*}{$\operatorname{aac}\left(6^{\prime}\right)-I I$} & $\mathrm{~F}$ & $5^{\prime}$-CGACCATTTCATGTCC-3' & [30] \\
\hline & $\mathrm{R}$ & 5'-GAAGGCTTGTCGTGTTT-3' & \\
\hline
\end{tabular}

vant institutions. Of these strains, 112 FQ-resistant and 100 FQsusceptible strains were examined further. The strains were isolated from the following clinical specimens: urine $(87 ; 41.0 \%)$, catheter urine $(76 ; 35.8 \%)$, sputum $(15 ; 7.1 \%)$, stool $(7 ; 3.3 \%)$, vaginal secretion $(6 ; 2.8 \%)$, pus $(3 ; 1.4 \%)$, aspiration tube $(3 ; 1.4 \%)$, drainage tube $(2 ; 0.9 \%)$, intravenous hyperalimentation catheter tube $(2 ; 0.9 \%)$, rhinorrhea $(2 ; 0.9 \%)$, ascites $(1 ; 0.5 \%)$, anal gland fluid $(1 ; 0.5 \%)$, decubitus $(1 ; 0.5 \%)$, injury site $(1 ; 0.5 \%)$, intestinal juice $(1 ; 0.5 \%)$, stoma $(1 ; 0.5 \%)$, PEG insertion site $(1 ; 0.5 \%)$, pharynx fluid $(1 ; 0.5 \%)$ and synovial fluid $(1 ; 0.5 \%)$.

\section{Antibiotic Susceptibility}

Susceptibility data for FQs were taken from our previous paper [15]. Gentamicin (GEN), amikacin (AMK) and tobramycin (TOB) were purchased from Wako Pure Chemical Industries (Osaka, Japan). The susceptibility was determined by minimum inhibitory concentration determined by the microdilution method, and disc diffusion method using Sensi-Disc (Beckton Dickinson, Franklin Lakes, N.J., USA). Breakpoints were according to the recommendations of the Clinical and Laboratory Standards Institute [26]. Screening for the presence of ESBLs was performed with SensiDisc of cefpodoxime, ceftazidime and clavulanic acid-ceftazidime according to the recommendations of the Clinical and Laboratory Standards Institute [27].

\section{Genetic Analysis}

Genomic DNA, which was used as the template for PCR, was isolated from bacterial cells using the QuickGene DNA tissue kit S (Fuji Film, Tokyo, Japan) and the QuickGene 800 system (Fuji Film). Genes encoding AG-modifying enzymes were detected by PCR using HotStarTaq polymerase (Qiagen, Hilden, Germany). The PCR primers [28-31] are listed in table 1. The PCR product for $a a c\left(6^{\prime}\right)-I b$ was sequenced with primer $5^{\prime}$-CGTCACTCCATA 
Table 2. AG resistance and genes encoding AG-modifying enzymes in FQ-resistant and susceptible E. coli strains

\begin{tabular}{|c|c|c|c|c|c|c|c|c|c|}
\hline & $\begin{array}{l}\text { Strains, } \\
\mathrm{n}\end{array}$ & GEN & ТОВ & AMK & $\begin{array}{l}\text { AG-modifying } \\
\text { enzyme gene }\end{array}$ & GEN & ТОВ & $\begin{array}{l}\text { Phylogenetic } \\
\text { group }\end{array}$ & Serogroup \\
\hline $\begin{array}{l}\text { FQ-resistant } \\
\text { O25b:H4-ST131 }\end{array}$ & 87 & R (22), I (0), S (65) & R (20), I (2), S (65) & R (0), I (0), S (85) & $\begin{array}{l}\operatorname{aac}(3)-I I(21) \\
\operatorname{ant}(2 ")-I(1)\end{array}$ & $\begin{array}{l}\mathrm{R}(21) \\
\mathrm{R}(1)\end{array}$ & $\begin{array}{l}\mathrm{R}(19), \mathrm{I}(2) \\
\mathrm{R}(1)\end{array}$ & B2 & $\mathrm{O} 25 \mathrm{~b}$ \\
\hline $\begin{array}{l}\text { FQ-resistant } \\
\text { other genotypes }\end{array}$ & 25 & R (8), I (0), S (17) & R (6), I (3), S (16) & R (1), I (0), S (24) & $\begin{array}{l}a a c(3)-I I(5) \\
a n t\left(2^{\prime \prime}\right)-I(1) \\
a a c(3)-I V(1) \\
a a c\left(6^{\prime}\right)-I b-c r(1) \\
\text { Not detected (1) }\end{array}$ & $\begin{array}{l}\mathrm{R}(5) \\
\mathrm{R}(1) \\
\mathrm{R}(1) \\
\mathrm{S}(1) \\
\mathrm{R}(1)\end{array}$ & $\begin{array}{l}\text { R (4), I (1) } \\
\text { R (1) } \\
\text { I (1) } \\
\text { R (1) } \\
\text { I (1) }\end{array}$ & $\begin{array}{l}\mathrm{D}(4), \mathrm{B} 2(1) \\
\mathrm{D}(1) \\
\mathrm{A}(1) \\
\mathrm{D}(1) \\
\mathrm{D}(1)\end{array}$ & $\begin{array}{l}\text { O1 (3), n.d. }{ }^{1}(2) \\
\text { n.d. (1) } \\
\text { n.d. (1) } \\
\text { O1 (1) } \\
\text { O153 (1) }\end{array}$ \\
\hline FQ-susceptible & 100 & R (2), I (0), S (98) & R (2), I (0), S (98) & R (0), I (0), S (100) & $\operatorname{aac}(3)-I I(2)$ & & & $\begin{array}{l}\mathrm{D}(1) \\
\mathrm{A}(1)\end{array}$ & n.d. (2) \\
\hline
\end{tabular}

Values in parentheses indicate the number of strains. GEN = Gentamicin; TOB = tobramycin; $\mathrm{AMK}=$ amikacin; $\mathrm{R}=$ resistant; $\mathrm{I}=$ intermediate; $\mathrm{S}=$ susceptible.

${ }^{1}$ n.d. - Serogroup could not be determined using the serogrouping antisera kit and multiplex PCR.

CATTGCAA- $3^{\prime}$ to identify the variant of $a a c\left(6^{\prime}\right)-\mathrm{Ib}-\mathrm{cr}$ [31]. ESBL genes were detected and identified as described previously [32]. Multilocus sequence type and phylogenetic groups were determined as described previously [15, 33]. Pulse-field gel electrophoresis was performed as described previously $[15,32]$. Serogroup determination of the O-serogroup was determined using E. coli antisera 'SEIKEN' Set 1 (DENKA Seiken, Tokyo, Japan) and multiplex PCR [34].

\section{Results}

E. coli isolates were classified into the following 3 groups: FQ-resistant O25b:H4-ST131 strains $(\mathrm{n}=87)$, FQ-resistant strains other than O25b:H4-ST131 ( $\mathrm{n}=25)$, and FQ-susceptible strains $(\mathrm{n}=100)$. We screened the AG resistance of these strains (table 2). The frequencies of GEN resistance were 25.3, 32.0 and $2.0 \%$, and those of TOB resistance were 23.0, 24.0 and $2.0 \%$ in the 3 groups, respectively. Only one isolate (an FQ-resistant strain other than O25b:H4-ST131) was resistant to AMK. The genes encoding AG-modifying enzymes were screened by PCR. Of the O25b:H4-ST131 strains, aac(3)-II and ant (2")- $I$ were found in 21 strains and 1 strain, respectively. All GEN-resistant O25b:H4-ST131 strains harbored one of them. Two aac(3)-II-carrying strains of them demonstrated intermediate resistance to TOB. Of the FQ-resistant strains other than O25b:H4-ST131, the genes of $\operatorname{aac}(3)-I I$ (5 strains), ant(2")-I (1 strain), aac(3)$I V$ (1 strain) and $a a c\left(6^{\prime}\right)-I b$ (1 strain) were found. The strains harboring these genes, except the isolate harboring aac (6')-Ib gene, were resistant to GEN. However, the genes encoding AG-modifying enzymes so far tested were not detected in 1 strain that was resistant to GEN and intermediate to TOB. One strain (O1-ST648) carrying the $a a c\left(6^{\prime}\right)-I b-c r$ was resistant to AMK and TOB. The cr variant of $a a c\left(6^{\prime}\right)-I b$ modifies not only AG, such as AMK, but also quinolones [35]. This is known as a plasmid-mediated quinolone resistance gene. Two FQ-susceptible strains that were resistant to GEN and TOB contained the aac(3)-II gene. The $16 \mathrm{~S}$ rRNA methylase genes $(\mathrm{rtm} A, \mathrm{rtmB}$, and $\operatorname{arm} A)$ were not detected in any strains (data not shown).

In our previous study [15], the presence of ESBL genes was examined in each of these E. coli strains. CTX-M-type ESBL genes were frequently found in FQ-resistant strains (32.2\% of O25b:H4-ST 131 strains and $32.0 \%$ of strains of other genotypes), but have not been detected in FQ-susceptible strains. The acquisition frequencies are similar to those of genes encoding AG-modifying enzymes. However, only 8 strains harbored both ESBL genes and genes encoding AG-modifying enzymes (table 3; fig. 1). All 8 strains were FQ resistant. The low frequency of the simultaneous occurrence of these two types of resistance genes indicated that they were acquired independently. The 8 strains comprised 4 O25b:H4-ST131 strains, 3 O1-ST648 strains and 1 ST167 strain. Strains SRE76 and SRE77 (O25b:H4-ST131) and strains SRE30 and SRE109 (O1ST648) had a similarity index of more than $90 \%$ of each (fig. 1). Although these pairs shared the same resistance genes, their QRDR mutation patterns differed (table 3), indicating that several strains showed a strong clonal relationship, but a varied genetic status. 
Fig. 1. Pulse-field gel electrophoresis patterns (XbaI digestion) and phylogenetic tree of $E$. coli isolates with both genes encoding AG-modifying enzymes and ESBL genes.

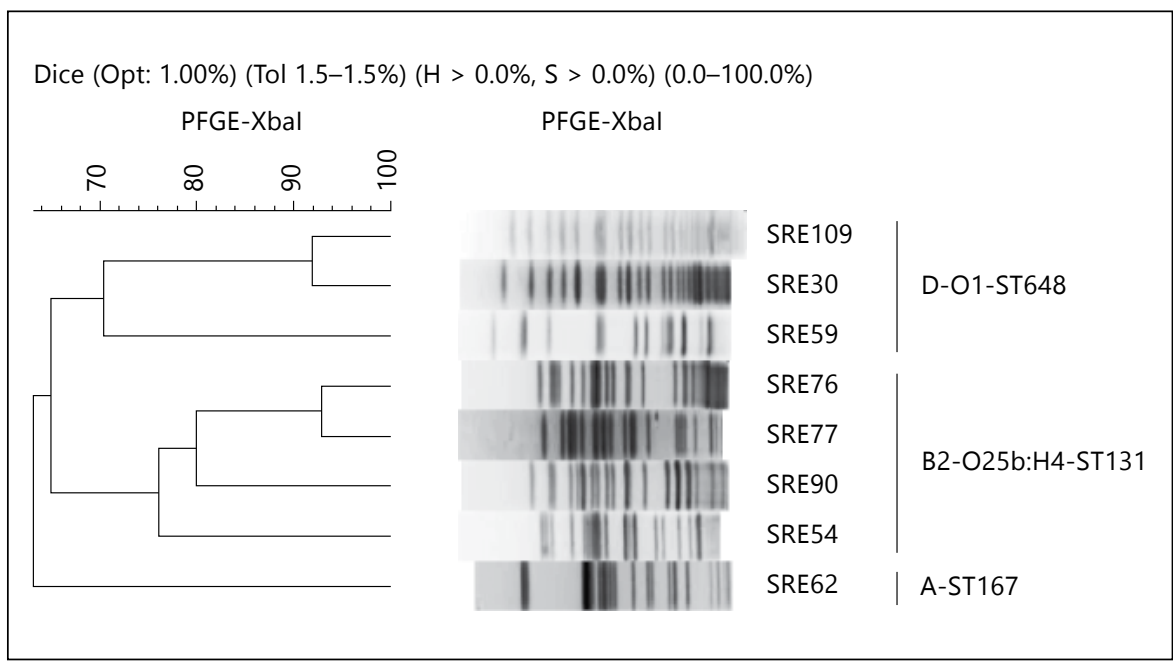

Table 3. Genotypes and resistance mechanisms of $E$. coli strains harboring both genes encoding AG-modifying enzymes and ESBL genes

\begin{tabular}{|c|c|c|c|c|c|}
\hline Strain & Genotype & $\begin{array}{l}\text { AG-modifying } \\
\text { enzyme gene }\end{array}$ & ESBL gene $^{1}$ & \multicolumn{2}{|c|}{ FQ resistance mutations other than $\mathrm{GyrA}^{2}$} \\
\hline SRE76 & B2-O25b:H4-ST131 & $\operatorname{aac}(3)-I I$ & CTX-M-2, TEM & Ser80Ile, Glu84Val & - \\
\hline SRE77 & B2-O25b:H4-ST131 & $\operatorname{aac}(3)-I I$ & CTX-M-2, TEM & Ser80Ile, Glu84Val & Leu445His \\
\hline SRE90 & B2-O25b:H4-ST131 & $\operatorname{aac}(3)-I I$ & CTX-M-27, TEM & Ser80Ile, Glu84Val & - \\
\hline SRE59 & D-O1-ST648 & $\operatorname{aac}(3)-I I$ & CTX-M-14, TEM & Ser80Ile & - \\
\hline SRE62 & A-ST167 & $\operatorname{aac}(3)-I V$ & CTX-M-2 & Ser80Ile & Glu460Val \\
\hline
\end{tabular}

${ }^{1}$ CTX-M-14 and CTX-M-27 are group 9, and CTX-M-2 is group 2.

${ }^{2}$ Mutations in gyrA (Ser83Leu and Asp87Asn) were the same in all strains.

\section{Discussion}

Multidrug-resistant Gram-negative bacteria, particularly those responsible for opportunistic infections, are a serious problem [7-9]. One example is the FQ-resistant E. coli O25b:H4-ST131 that has spread globally [10, 11, 13], and frequently acquires CTX-M-type ESBL genes. Our recent findings [15] show that CTX-M genes were frequently found not only in O25b:H4-ST131, but also in other genotypes of FQ-resistant $E$. coli isolated from the Hokkaido Prefecture, Japan. In contrast, CTX-M genes were rarely found in FQ-susceptible strains. There is great concern that strains that are resistant to particular antibiotics may acquire resistance to other antibiotics more frequently than non-resistant strains, generating multidrug- resistant strains of $E$. coli. A recent nationwide survey in the urology field in Japan indicated that, of the isolates examined, less than $10 \%$ were resistant to GEN and none were resistant to AMK [5]. Our present study showed a similar frequency of GEN resistance in all E. coli strains. On the other hand, the incidence of GEN resistance and genes encoding AG-modifying enzymes were much higher in the FQ-resistant strains, including O25b:H4-ST131 and other genotypes, than in FQ-susceptible strains. The simultaneous occurrence of genes encoding AG-modifying enzymes and ESBL CTX-M genes was relatively low (fig. 2), suggesting they were acquired independently.

E. coli strains harboring both types of resistance genes are B2-O25b:H4-ST131, D-O1-ST648 and A-ST167. The latter two ST types are frequently identified as ESBL-car- 


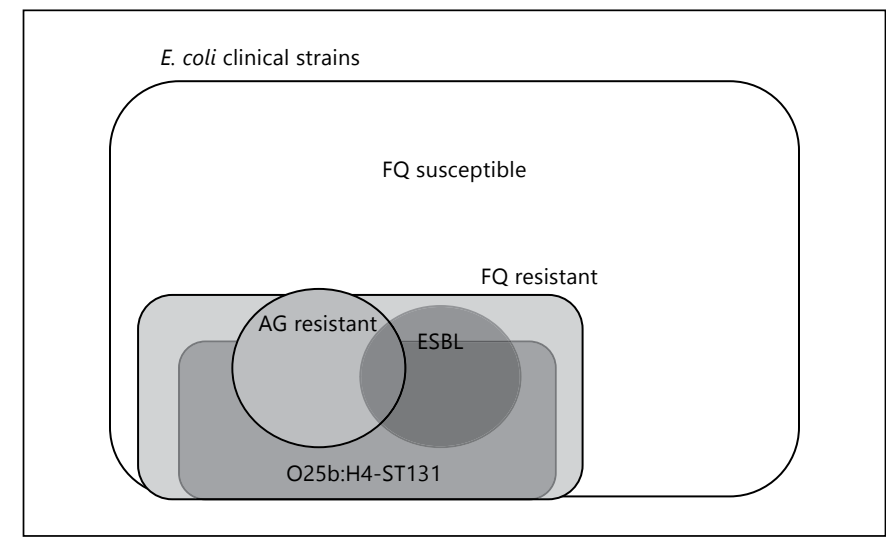

Fig. 2. Schematic representation of antimicrobial resistance in E. coli clinical isolates.

rying E. coli isolates not only in humans, but also in veterinary fields $[32,33,36-38]$. Notably, of 5 D1-O1-ST648 strains in 212 strains examined in the present study, 3 strains harbored both aac(3)-II and CTX-M-type ESBL genes (table 3), and another D1-O1-ST648 strain harbored the $a a c\left(6^{\prime}\right)-I b-c r$ gene and was resistant to AMK. Our findings identified two pairs of clonally related strains with the same foreign genes (fig. 1; table 3); however, their
QRDR mutation patterns were different. These results suggest that these resistant clones are continuing to evolve by acquiring further resistance. The main mechanism of FQ resistance is somatic mutations in topoisomerase IV and DNA gyrase, which should be independent of the acquisition of foreign genes, such as genes encoding $\beta$-lactamases and AG-modifying enzymes. It is unclear why FQ-resistant $E$. coli preferentially acquired these resistance genes. One explanation is that bacteria resistant to one antibiotic may be frequently exposed to other antibiotics. Particularly, bacteria causing chronic and repetitive infections, especially opportunistic infections, may receive numerous antibiotic pressures and selection.

In conclusion, in comparison to strains that were FQsusceptible, FQ-resistant strains of $E$. coli were frequently resistant to other antibiotics, such as AGs and cephems, including not only O25b:H4-ST131, but also other genotypes.

\section{Acknowledgments}

This study was partly supported by a grant program for developing the supporting system for upgrading education and research by the Japan Ministry of Education, Culture, Sports, Science and Technology, and by a grant from the Yuasa Memorial Foundation.

\section{References}

1 Kaper JB, Nataro JP, Mobley HL: Pathogenic Escherichia coli. Nat Rev Microbiol 2004;2: 123-140.

2 Mandell GL, Douglas RG, Bennett JE, Dolin R: Mandell, Douglas, and Bennett's Principles and Practice of Infectious Diseases, ed 6. New York, Churchill Livingstone, 2005.

3 Foxman B: The epidemiology of urinary tract infection. Nat Rev Urol 2010;7:653660.

4 Schaeffer A: Infections of the urinary tract; in Wein A, Kavoussi L, Novick A, Partin AW, Peters CA (eds): Campbell-Walsh Urology, ed 9. Philadelphia, Saunders Elsevier, 2007, pp 223-303.

5 Hayami $\mathrm{H}$, Takahashi S, Ishikawa K, et al: Nationwide surveillance of bacterial pathogens from patients with acute uncomplicated cystitis conducted by the Japanese surveillance committee during 2009 and 2010: antimicrobial susceptibility of Escherichia coli and Staphylococcus saprophyticus. J Infect Chemother 2013;19:393-403.

6 Pitout JD, Laupland KB: Extended-spectrum $\beta$-lactamase-producing Enterobacteriaceae: an emerging public-health concern. Lancet Infect Dis 2008;8:159-166.
7 Falagas ME, Karageorgopoulos DE: Extended-spectrum $\beta$-lactamase-producing organisms. J Hosp Infect 2009;73:345-354.

$>8$ Pitout JD: Extraintestinal pathogenic Escherichia coli: an update on antimicrobial resistance, laboratory diagnosis and treatment. Expert Rev Anti Infect Ther 2012;10:11651176.

-9 Lynch JP 3rd, Clark NM, Zhanel GG: Evolution of antimicrobial resistance among Enterobacteriaceae (focus on extended spectrum $\beta$-lactamases and carbapenemases). Expert Opin Pharmacother 2013;14:199210.

10 Woodford N, Turton JF, Livermore DM: Multiresistant Gram-negative bacteria: the role of high-risk clones in the dissemination of antibiotic resistance. FEMS Microbiol Rev 2011;35:736-755.

-11 Peirano G, Pitout JD: Molecular epidemiology of Escherichia coli producing CTX-M $\beta$-lactamases: the worldwide emergence of clone ST131 O25:H4. Int J Antimicrob Agents 2010;35:316-321.

12 Nicolas-Chanoine MH, Blanco J, Leflon-Guibout V, Demarty R, Alonso MP, Canica MM, Park YJ, Lavigne JP, Pitout J, Johnson JR: Intercontinental emergence of Escherichia coli clone O25:H4-ST131 producing CTX-M-15. J Antimicrob Chemother 2008;61:273-281.

-13 Coque TM, Novais A, Carattoli A, Poirel L, Pitout J, Peixe L, Baquero F, Canton R, Nordmann P: Dissemination of clonally related Escherichia coli strains expressing extendedspectrum $\beta$-lactamase CTX-M-15. Emerg Infect Dis 2008;14:195-200.

14 Suzuki S, Shibata N, Yamane K, Wachino J, Ito $\mathrm{K}$, Arakawa Y: Change in the prevalence of extended-spectrum- $\beta$-lactamase-producing Escherichia coli in Japan by clonal spread. J Antimicrob Chemother 2009;63:72-79.

-15 Yokota S, Sato T, Okubo T, Ohkoshi Y, Okabayashi T, Kuwahara O, Tamura Y, Fujii N: Prevalence of fluoroquinolone-resistant Escherichia coli O25:H4-ST131 (CTX-M-15-nonproducing) strains isolated in Japan. Chemotherapy 2012;58:52-59.

16 Yano H, Uemura M, Endo S, Kanamori H, Inomata $S$, Kakuta $R$, Ichimura $S$, Ogawa $M$, Shimojima M, Ishibashi N, Aoyagi T, Hatta M, Gu Y, Yamada M, Tokuda K, Kunishima H, Kitagawa M, Hirakata Y, Kaku M: Molecular characteristics of extended-spectrum $\beta$-lactamases in clinical isolates from Escherichia coli at a Japanese tertiary hospital. PLoS One 2013;8:e64359. 
17 Guiral E, Bosch J, Vila J, Soto SM: Antimicrobial resistance of Escherichia coli strains causing neonatal sepsis between 1998 and 2008. Chemotherapy 2012;58:123-128.

18 Ho P-L, Chen VCC: Epidemiology and mechanisms of resistance; in Ronald AR, Low DE (eds): Fluoroquinolone Antibiotics. Basel, Birkhauser, 2003, pp 49-71.

19 Walsh C: Enzymatic destruction or modification of the antimicrobial bacteria; in Walsh C (ed): Antibiotics: Actions, Origins, Resistance. Washington, American Society for Microbiology, 2003, pp 106-123.

20 Jana S, Deb JK: Molecular understanding of aminoglycoside action and resistance. Appl Microbiol Biotechnol 2006;70:140-150.

21 Vakulenko SB, Mobashery S: Versatility of aminoglycosides and prospects for their future. Clin Microbiol Rev 2003;16:430-450.

22 Shaw KJ, Rather PN, Hare RS, Miller GH: Molecular genetics of aminoglycoside resistance genes and familial relationships of the aminoglycoside-modifying enzymes. Microbiol Rev 1993;57:138-163.

23 Shakya T, Wright GD: Mechanisms of aminoglycoside antibiotic resistance; in Arya DP (ed): Aminoglycoside Antibiotics: from Chemical Biology to Drug Discovery. Hoboken, John Wiely \& Sons, 2007, pp 119-140.

24 Wachino J, Arakawa Y: Exogenously acquired $16 \mathrm{~S}$ rRNA methyltransferases found in aminoglycoside-resistant pathogenic Gram-negative bacteria: an update. Drug Resist Updat 2012;15:133-148.
25 Magnet S, Blanchard JS: Molecular insights into aminoglycoside action and resistance. Chem Rev 2005;105:477-498.

26 Clinical and Laboratory Standards Institute: Methods for dilution antimicrobial susceptibility tests for bacteria that grow aerobically; approved standard 8th edition. CLSI document M07-A8. Wayne, CLSI, 2009.

27 Clinical and Laboratory Standards Institute: Performance standards for antimicrobial susceptibility testing. Twentieth informational supplement, M100-S20. Wayne, CLSI, 2010.

28 van de Klundert JAM, Vliegenthart JS: PCR detection of genes coding for aminoglycoside-modifying enzymes; in Persing $\mathrm{DH}$, Smith TF, Tenover FC, White TJ (eds): Diagnosstic Molecular Microbiology. Washington, American Society for Microbiology, 1993, pp 547-552.

29 Sandvang D, Aarestrup FM: Characterization of aminoglycoside resistance genes and class 1 integrons in porcine and bovine gentamicin-resistant Escherichia coli. Microb Drug Resist 2000;6:19-27.

$30 \mathrm{Hu}$ X, Xu B, Yang Y, Liu D, Yang M, Wang J, Shen H, Zhou X, Ma X: A high throughput multiplex PCR assay for simultaneous detection of seven aminoglycoside-resistance genes in Enterobacteriaceae. BMC Microbiol 2013;13:58.

31 Park CH, Robicsek A, Jacoby GA, Sahm D, Hooper DC: Prevalence in the United States of $a a c\left(6^{\prime}\right)-I b-c r$ encoding a ciprofloxacinmodifying enzyme. Antimicrob Agents Chemother 2006;50:3953-3955.

32 Okubo T, Sato T, Yokota S, Usui M, Tamura Y: Comparison of broad-spectrum cepharosporin-resistant Escherichia coli isolated from dogs and humans in Hokkaido, Japan. J Infect Chemother 2014;20:243-249.

- 33 Sato T, Yokota S, Okubo T, Usui M, Fujii N, Tamura Y: Phylogenetic association of fluoroquinolone and cephalosporin resistance of D-O1-ST648 Escherichia coli carrying bla $a_{\mathrm{CMY}-2}$ from faecal samples of dogs in Japan. J Med Microbiol 2014;63:263-270.
34 Clermont O, Johnson JR, Menard M, Denamur E: Determination of Escherichia coli $\mathrm{O}$ types by allele-specific polymerase chain reaction: application to the $\mathrm{O}$ types involved in human septicemia. Diagn Microbiol Infect Dis 2007;57:129-136.

35 Robicsek A, Strahilevitz J, Jacoby GA, Macielag $\mathrm{M}$, Abbanat $\mathrm{D}$, Park $\mathrm{CH}$, Bush $\mathrm{K}$, Hooper DC: Fluoroquinolone-modifying enzyme: a new adaptation of a common aminoglycoside acetyltransferase. Nat Med 2006;12: 83-88.

36 Wieler LH, Ewers C, Guenther S, Walther B, Lubke-Becker A: Methicillin-resistant staphylococci (MRS) and extended-spectrum $\beta$-lactamases (ESBL)-producing Enterobacteriaceae in companion animals: nosocomial infections as one reason for the rising prevalence of thesepotential zoonotic pathogens in clinical samples. Int J Med Microbiol 2011;301:635-641.

37 Schink AK, Kadlec K, Kaspar H, Mankertz J, Schwarz S: Analysis of extended-spectrum- $\beta$ lactamase-producing Escherichia coli isolates collected in the GERM-Vet monitoring programme. J Antimicrob Chemother 2013;68: 1741-1749.

38 Guenther S, Aschenbrenner K, Stamm I, Bethe A, Semmler T, Stubbe A, Stubbe M, Batsajkhan N, Glupczynski Y, Wieler LH, Ewers $C$ : Comparable high rates of extendedspectrum- $\beta$-lactamase-producing Escherichia coli in birds of prey from Germany and Mongolia. PLoS One 2012;7:e53039. 